\title{
PERANAN KIAI DAN PESANTREN CIPARI GARUT MENGHADAPI DI/TII (1948-1962)
}

\author{
Oleh Iim Imadudin \\ Balai Pelestarian Sejarah dan Nilai Tradisional Bandung \\ Jln. Cinambo No. 136 Ujungberung Bandung \\ Email: iim.imadudin@yahoo.com
}

Naskah diterima: 22 Desember 2009

Naskah disetujui: 12 Februari 2010

\begin{abstract}
Abstrak
Tulisan ini bertujuan mengungkap peranan salah satu pesantren bersejarah di Garut Jawa Barat, yaitu Pesantren Cipari. Pesantren ini sejak awal perkembangannya memang lekat dengan perjuangan kebangsaan. K.H. Yusuf Tauziri dan beberapa kiai lainnya memimpin gerakan Sarekat Islam di Garut tahun 1920 hingga 1930-an. Ujian kesetiaan terhadap Republik terjadi ketika gerakan DI/TII di tahun 1948 melakukan perlawanan terhadap pemerintah. Pihak pesantren dengan tegas mendukung pemerintah, sebagaimana terepresentasikan dalam sikap pemimpinnya, K.H. Yusuf Tauziri. Maka, konflik antara pihak pesantren dan pasukan DI/TII tidak terhindarkan. Tulisan ini sebagian besar berasal dari kesaksian lisan tokoh-tokoh Pesantren Cipari dan sumber tertulis lainnya. Memahami kiprah Pesantren Cipari berarti pula memahami perjuangan kebangsaan secara keseluruhan, khususnya pada masa konflik sosial setelah kemerdekaan.
\end{abstract}

Kata kunci: pesantren, Cipari, DI/TII.

\section{Abstract}

This article aims to reveal the role of one of the historical pesantren in Garut West Java, that is Pesantren Cipari. This Pesantren since beginning of its the development is closely related to the struggle of nationalism. K.H. Yusuf Tauziri and some other kiai leads movement Sarekat Islam in Garut in 1920 until 1930s. Examination of fidelity to the Republic occurred when movement DI/TII in 1948 to fight against the government. Pesantren Cipari firmly supports the government, as in the attitude of the leaders, K.H. Yusuf Tauziri. Thus, the conflict between Pesantren Cipari and forces DI/TII inevitable. This paper is largely derived from oral testimony of Pesantren Cipari leaders and other written sources. Understanding the role of Pesantren Cipari also means understanding the nationalist struggle as a whole, especially during social conflicts after independence.

Keywords: pesantren, Cipari, DI/TII.

\section{A. PEndAhuluan}

Dalam sejarah perjuangan nasional, pesantren memainkan peranan dikenal sebagai lembaga pendidikan tradisional ternyata menghasilkan yang penting. Identitas pesantren yang tokoh yang turut berperan pada awal 
kemerdekaan. Beberapa di antaranya terlibat dalam usaha merumuskan konstitusi negara. Selain itu, para ulama dan santri tampil ke garis depan melawan penjajahan. Spirit jihad membela agama dan tanah air menjadi dasar perjuangannya. Demikian pula, setelah kemerdekaan, para ulama dan santri di pesantren-pesantren yang tersebar di penjuru tanah air, terlibat dalam upaya mempertahankan kemerdekaan dan integrasi bangsa. Salah satu pesantren yang terlibat dalam kancah pergolakan sosial adalah Pesantren Cipari di Kabupaten Garut.

Masalah pokok dari penelitian ini adalah "Bagaimana peranan kiai dan Pesantren Cipari dalam pergolakan sosial?" Tujuan penelitian ini adalah untuk memperoleh deskripsi tentang eksistensi Pesantren Cipari dan peranannya dalam kurun waktu 19481962 secara kronologis. Dari segi akademik, hasil penelitian ini diharapkan dapat memperkaya khasanah kepustakaan mengenai sejarah pesantren.

Zamakhsari Dhofier dalam Tradisi Pesantren (1985) menguraikan konsep kiai sebagai elemen yang paling esensial dari suatu pesantren. Menurut asal usulnya, perkataan kiai dalam bahasa Jawa dipakai untuk tiga jenis gelar yang saling berbeda: yaitu pertama sebagai gelar kehormatan bagi barang-barang yang dianggap keramat, umpamanya "Kyai Garuda Kencana" dipakai untuk sebutan kereta emas yang berada di keraton Yogyakarta; kedua sebagai gelar kehormatan untuk orangorang tua pada umumnya; ketiga gelar yang diberikan oleh masyarakat kepada ahli agama Islam yang memiliki atau menjadi pimpinan pesantren dan mengajar kitab-kitab klasik kepada para santrinya. Selain gelar kiai, ia sering juga disebut seorang alim yaitu orang yang dalam pengetahuan Islamnya.

Clifford Geertz dalam "the Javanese Kiyayi: the Changing Roles of a Cultural Broker" menyebut kiai sebagai penghubung budaya antara pesantren dan "dunia luar". Menurut teori ini, kiai berperan membendung dampak negatif dari arus budaya luar yang masuk ke dalam kehidupan masyarakat Jawa, dengan risiko derasnya arus budaya yang masuk akan jauh melampaui kapasitas kerja sebagai bendungan itu sendiri.

Manfred Ziemek (1986), memfokuskan kajian pada pesantren dan perannya dalam perubahan sosiokultural dan perannya bagi masyarakat pedesaan. Ia telah membuktikan bahwa pesantren merupakan lembaga pendidikan yang berpengaruh penting bagi perubahan sosial masyarakat desa. Dampak pada masyarakat berlangsung secara tidak alami, tetapi melalui suatu rekayasa sosial.

Hiroko Horikoshi (1982) dalam studinya tentang peranan ajengan Yusuf Tauziri (Pesantren Cipari Garut) mengklarifikasi hipotesis Geertz. Kiai tidak berperan pasif, justru berperan aktif melakukan seleksi atas nilai-nilai dan sikap-sikap positif yang seharusnya dikembangkan oleh masyarakat, dan dengan demikian merumuskan skala prioritas sendiri atas perubahan masyarakat dan mengembangkan kepeloporan mereka dalam proses perubahan itu sendiri. Sementara nilai-nilai agama tetap tak berubah, perilaku-perilaku politik berubah sama sekali di bawah pimpinan kiai desa yang sama.

Studi terbaru Suparta memperkaya dan memperlihatkan perbedaan 
dengan penelitian sebelumnya yang dilakukan Manfred Ziemek dan Hiroko Horikoshi. Menurut Suparta, baik Ziemek maupun Horikoshi yang membahas peran pesantren dalam perubahan sosial sama-sama tidak mengaitkan perubahan internal pesantren dengan perubahan eksternal masyarakat. Keterkaitan antara dua variabel inilah yang membedakan disertasinya dengan dua penelitian tersebut, terutama perubahan orientasi pesantren yang berisi corak paham keagamaan. Demikianlah, secara umum perkembangan dalam studi pesantren yang telah dilakukan. Bagi penelitian setelahnya, tetap terbuka kemungkinan untuk meninjau kembali teori dan konsep-konsep tentang lembaga pendidikan tradisional tersebut. ${ }^{1}$

Hubungan antara pelaku (tokoh) dalam lembaga dengan konteks lingkungannya terjalin sangat erat. Hal tersebut dapat diletakkan dalam jiwa zamannya (zeitgeist). Pendekatan deterministik idealistik ini dipakai kaum idealis untuk sejarah jangka panjang. Pemahaman terhadap jiwa zaman (zeitgeist) dapat mengungkapkan keterkaitan pikiran dan tindakan dengan situasi yang melingkupinya. Kuntowijoyo menyebutnya sebagai sensibility (kandungan emosional suatu kurun sejarah).

Penelitian ini sebagian besar menggunakan metode sejarah lisan. Sejarah lisan dirumuskan James $\mathrm{H}$. Morrison (2000: xiv) sebagai "pengumpulan bahan-bahan melalui perbincangan atau wawancara dengan satu orang atau lebih mengenai satu masalah yang

1 "Dampak Perubahan Orientasi Pondok Pesantren terhadap Masyarakat", dalam http: www.pondokpesantren.net, 24 September 2008 sedang dipelajari oleh sang pewawancara". Selanjutnya, penelitian ini menggunakan metode historis yang terdiri atas empat tahapan, yaitu heuristik, kritik, interpretasi, dan historiografi.

\section{B. HASIL DAN BAHASAN \\ 1. Potret Pesantren Cipari}

Pesantren Cipari terletak di Kampung Cipari Desa Sukarasa Kecamatan Pangatikan Kabupaten Garut. Kampung Cipari memiliki luas sekitar sepuluh hektar, dengan pemukiman penduduk yang memusat di sekitar komplek Pesantren Cipari Darussalam. Di beberapa bagian tampak pesawahan yang menghijau. Dalam ingatan kolektif masyarakat, penyebaran Islam ke Kampung Cipari berlangsung pada permulaan abad ke18. Tokoh utamanya adalah Zaenal Abidin yang dipandang sebagai peletak dasar komunalitas penduduk Cipari. ${ }^{2}$

Apabila dilacak pada proses pertumbuhannya, Pesantren Cipari merupakan kelanjutan Pesantren Cidewa dan Cilame yang sudah ada sejak tahun 1873. Kedua pesantren tersebut dipimpin K.H. Abdul Karim, K.H. Syamsudin, K.H. Abdullah, dan K.H. Hasan. Akibat ketiadaan ulama

2 Zaenal Abidin menikahi perempuan setempat yang bernama Wah. Dari pernikahan itu terlahir empat orang anak, yaitu Abu Kaim, Esti, Qomaruddin, dan Syamsuddin. Syamsudin menikah dan mempunyai beberapa orang anak. Salah satu di antara putranya bernama Harmain (sering juga ditulis Harmaen). Kemudian, dari keluarga kecil yang dirintis Zainal Abidin lamalama berkembang menjadi satu komunitas. Akhirnya, tumbuh satu perkampungan yang berasal dari satu keturunan yang sama. Itulah sebabnya pertalian darah antara sesama masyarakat Cipari begitu kuat. 
pengasuh pondok karena meninggal dan beberapa ulama lainnya bermukim di tanah suci, sejak tahun 1894 kedua pesantren itu mengalami kevakuman. Terjadi krisis kepemimpinan ulama yang menyebabkan pesantren mengalami kemandekan.

Keadaan tersebut tidak berlangsung lama. Beberapa ulama memandang perlu dibukanya kembali pesantren untuk membina aqidah umat. Pada tahun 1895 K.H. Harmaen, K.H. Ahmad Kisya, dan K.H. Ahmad Zainal membuka pesantren di Kampung Cipari. Lokasi pesantren Cipari berjarak sekitar 200 meter arah barat daya Pesantren Cilame. Oleh sebab berdiri di Cipari, maka pesantren itu dinamakan Pesantren Cipari. Alasan pemilihan lokasi dilatarbelakangi oleh kesuburan tanah daerah ini dan sumber air yang melimpah. ${ }^{3}$ Selain diperlukan untuk kebutuhan manusia sehari-hari dan dipakai untuk aktivitas pertanian, air juga menjadi pendukung bagi pelaksanaan ajaran bersuci dalam Islam. Oleh karena itu, keberadaan air menempati prioritas penting dalam pendirian pesantren.

Para santri Pesantren Cidewa dan Cilame kemudian pindah ke Pesantren Cipari. Aktivitas pendidikan di kedua pesantren tersebut sebagaimana disebutkan di atas telah mengalami kemandekan. Di luar santri Cidewa dan Cilame, calon-calon santri baru yang berasal dari daerah sekitar Cipari terus berdatangan. Dengan demikian, bangunan yang lama tidak lagi mampu

\footnotetext{
Asep Tedi Rismawan. 2008. Perlawanan Laskar Darusslam terhadap Gerakan DI/TII di Wanaraja Garut 1948-1952. Skripsi. Jurusan Sejarah dan Peradaban Islam, UIN SGD Bandung, hlm. 21
}

menampung santri. Prioritas penambahan bangunan pondok harus dilakukan. Tanggung jawab penambahan fasilitas pondok berada di tangan pembina dan tokoh masyarakat. Para santri tidak harus direpotkan dengan hal-hal tersebut. Kewajiban mereka adalah belajar dengan sebaik-baiknya dan mengikuti segala tata aturan yang berlaku di pesantren.

K.H. Zakaria, K.H. Adrai, K.H. Abdullah, K.H. Abdul Fatah, K.H. Sarbini, dan K.H. Bakri yang menjadi pembina pondok memang tergolong sebagai kalangan mampu. K.H. Harmain, misalnya, dikenal memiliki banyak serang (sawah). Setiap pengajian digelar, ia selalu menyediakan makanan dan lauk-pauk untuk hadirin yang datang. ${ }^{4}$ Keberlangsungan pesantren didukung oleh kemampuan ekonomi ulama pengasuh dan donatur lainnya. Dalam sistem pendidikan pesantren tradisional tidak dikenal adanya penerimaan dana khusus dari santri. Orang tua santri dapat memberi semampunya dan tidak selalu berupa uang.

Masjid menjadi pusat spiritual dari sistem pendidikan tradisional. Cikal bakal Masjid Cipari adalah bangunan yang secara sederhana didirikan pada tahun 1895 oleh K.H. Harmain. Pembangunannya dilakukan secara bergotong royong yang melibatkan keluarga pesantren, santri, dan masyarakat. Pada mulanya masjid berada di dalam komplek pesantren yang dikelilingi sekitar dua puluh rumah penduduk.

Pada tahun 1933, K.H. Harmain sebagai pendiri pesantren, wafat.

${ }^{4}$ Wawancara H. Syarif Hidayat, Cipari, 30 April 2009 
Kepemimpinan pesantren beralih ke tangan K.H. Yusuf Tauziri. Kiai Yusuf memang dipersiapkan untuk melanjutkan estafet kepemimpinan pesantren. Ketika dipimpin K.H. Yusuf Tauziri, masjid dibangun dan diperluas seiring dengan perkembangan pesat yang dialami pesantren. Penambahan bangunan diperlukan untuk menampung lebih banyak jamaah. Konsultan dari pembangunan masjid itu adalah seorang tokoh pergerakan yang bernama Abikoesno Tjokrosujoso.

Pada masa pergerakan masjid ini memang digunakan sebagai tempat rapat-rapat organisasi Islam. Masjid tidak saja menjadi pusat ibadah, tetapi juga pusat kehidupan sosial. Al-Qur'an menganjurkan agar umat Islam bermusyawarah untuk menyelesaikan segala perkara. ${ }^{5}$ Atas dasar itu, masjid tersebut diberi nama Masjid As-Syuro, yang artinya tempat bermusyawarah. Namun, dalam keseharian lebih dikenal dengan sebutan Masjid Cipari. Arsitektur masjid ini memang unik dan kental dengan gaya art deco. Rupanya, sebagai seorang yang berpendidikan Belanda, yang saat itu tengah dilanda demam art deco, Abikusno pun memakai gaya yang sama. Setelah bangunannya selesai, para tokoh dan masyarakat yang ikut membangun cukup kaget melihat hasilnya. Pembangunannya dirampungkan pada tahun 1935. Luas bangunan kurang lebih $75 \mathrm{x}$ 30 meter. Bentuk masjid dan menara tidak berbeda dengan kondisi sekarang. Meskipun ada penambahan hanya pada

${ }^{5}$ Ada tiga ayat dalam Al-Qur'an yang akar katanya menunjuk pada musyawarah, yaitu Al-Baqarah:233; Ali 'Imron:159; dan AlSyura:38. bangunan yang ada di sebelahnya. Para kiai, bahkan sengaja mempertahankan bentuk aslinya sebagai monumen ingatan untuk generasi mendatang agar sejarah tidak dilupakan sehingga nilainilainya tetap lestari.

Pada tahun 1940 K.H. Yusuf Tauzirie mendirikan masjid dan madrasah di Wanaraja. Ia menamakannya "Darussalam". Dengan adanya masjid dan madrasah tersebut, Pesantren Cipari lebih dikenal di lingkungan masyarakat dengan nama Pesantren Darussalam Cipari. Kata "Darussalam" berarti tempat yang penuh kedamaian dan keselamatan.

Ikatan sosial yang kuat tidak hanya berlaku bagi penduduk yang lebih dahulu menempati wilayah ini, tetapi juga para pendatang yang tiba kemudian. Sebagian dari para pendatang itu menikah dengan gadis setempat. Adapun tujuan kedatangan mereka adalah mencari perlindungan disebabkan adanya ancaman terhadap diri mereka. Para pengungsi menjadi korban dari situasi penjajahan yang mengancam jiwanya. Hal tersebut tidak saja terjadi di masa itu, bahkan setelah kemerdekaan. Fase pascakemerdekaan dipenuhi oleh serangkaian gejolak sosial di daerah-daerah yang umumnya dipicu oleh ketidakpuasan terhadap kebijakan pusat. Setelah suasana kembali normal, khususnya tahun 1970-an dan seterusnya, motivasi pada pendatang diduga lebih banyak dilatari oleh motivasi ekonomi. Sampai tahun 1980-an, hampir sembilan puluh persen masyarakat Cipari merupakan keluarga pesantren. ${ }^{6}$ Setelah fase itu makin banyak para pendatang yang menetap April 2009

${ }^{6}$ Wawancara Nasrul Fuadz, Cipari, 30 
di tempat tersebut. Meski demikian, kohesi sosial antarpenduduk masih tetap kuat, karena ada satu ikatan kultural yang sama, yaitu agama Islam.

\section{Sikap Pesantren Cipari terhadap DI/TII}

Setelah Pesantren Cipari dikenal dengan nama Pesantren Darussalam, eksistensi pesantren terganggu oleh anasir luar, khususnya kemunculan DI/TII dan gerakannya yang menentang pemerintah RI. Tokoh penting gerakan DI/TII adalah S.M. Kartosuwirjo.

S.M. Kartosuwirjo mendirikan Lembaga "Suffah" pada tanggal 24 Maret 1940 di Bojong, Malangbong Balubur Limbangan Garut. Hal tersebut dilakukan untuk memperkuat gagasan Negara Islam Indonesia (NII). Pada praktiknya, lembaga tersebut memiliki banyak fungsi, antara lain sebagai pesantren, tempat latihan kemiliteran bagi Hizbullah dan Sabilillah, dan sarana propaganda pembentukan Negara Islam. ${ }^{7}$ Para pengajarnya berasal dari sejumlah ulama terkemuka di Jawa Barat. ${ }^{8}$

Pada tanggal 13 Juli 1947, S.M. Kartosuwirjo ditawari menjadi Wakil

7 Pada mulanya lembaga tersebut mampu menerapkan sistem pendidikan modern yang mengkombinasikan masalah agarna, pelajaran bahasa Belanda, astronomi, dan doktrin Islam militan. K.H. Yusuf Tauziri secara tidak langsung mendukung Suffah. Ia mengirimkan dua anak laki-lakinya dan seorang keponakan sebagai pengajar dan pelajar. Namun, tidak semua anggota yang telah menyerahkan hartanya untuk Suffah bersedia menjalani cara hidup penuh disiplin itu, terutama para bekas tuan tanah.

8 Irfan S. Awwas, Jejak Jihad S.M. Kartosuwirjo: Mengungkap Fakta yang Didustakan (Yogyakarta: Uswah), 2008, hlm. 110
Menteri Pertahanan dalam Kabinet Amir Syarifudin. Tawaran itu ditolaknya, karena ia loyal dengan partai Masyumi yang jelas-jelas menentang Perjanjian Linggajati. Selain itu, rupanya S.M. Kartosuwirjo berniat untuk mundur dari lingkar elit kekuasaan, dan berkonsentrasi mengkonsolidasikan kekuatannya di Malangbong Garut. Di kota tersebut ia membidani lahirnya Dewan Pertahanan Umat Islam (DPUI) di Garut dan Majelis Umat Islam Indonesia (MUUI) di Tasikmalaya. ${ }^{9}$

Ketika Belanda melancarkan agresi militernya yang pertama pada tanggal 21 Juli 1947, kota-kota penting di Priangan Timur, seperti Garut, Tasikmalaya, dan Ciamis dikuasai. S.M. Kartosuwirjo mengobarkan Perang Suci menentang Belanda. Ia menentang apapun kompromi dengan Belanda. Hasil Persetujuan Renville pada bulan Januari 1948 diingkarinya. Bahkan ia menolak menarik mundur kelompok-kelompok Hizbullah dan Sabilillah ke belakang garis demarkasi. Secara langsung, ia terlibat dalam kontestasi antara para pemimpin Republik dengan pemimpin Masyumi.

Konsekuensi yang ditanggung pihak Republik akibat Perundingan Renville sungguh berat. Divisi Siliwangi dan laskar perjuangan harus hijrah ke Yogyakarta. Laskar Darussalam dipimpin E. Saepudin dan A. Gofar SK (putra K.H. Abdul Kudus) turut pula hijrah. Daerah-daerah yang ditinggalkan segera jatuh ke tangan Belanda.Tidak ada lagi kekuatan Republik yang melawan tentara Belanda. Dalam suatu pertemuan di Cisayong Tasikmalaya pada tanggal 10

\footnotetext{
${ }^{9}$ Asep Tedi Rismawan Op. cit., hlm. 43
} 
Februari 1948 ditegaskan bahwa organisasi-organisasi Gabungan Pemuda Islam Indonesia (GPII) dan Sabilillah yang hendak hijrah harus menyerahkan senjata kepada Hizbullah. Sementara itu, segala aktivitas Masyumi harus dibekukan. Keputusan tersebut hendak memunculkan pendapat umum bahwa Masyumi dan organisasi-organisasi perjuangan sudah tidak ada.

Beberapa pemimpin Masyumi, seperti S.M. Kartosuwirjo, Sanusi Partawijaya, dan Toha Arshad yang mengikuti permusyawaratan tersebut tidak kembali. Mereka mengadakan pertemuan sendiri. Hasilnya adalah terbentuk organisasi yang bersendikan agama Islam, yaitu Darul Islam dengan pasukannya yang dinamakan Tentara Islam Indonesia (TII). Darul Islam (Dar al-Islam) berarti "rumah" atau "keluarga" Islam, yaitu dunia atau wilayah Islam tempat diberlakukannya syariat Islam. Lawan dari Darul Islam adalah Darul Harb, yaitu "wilayah perang, dunia kaum kafir" yang berangsur-angsur akan menjadi bagian Dar al-Islam. Lama kelamaan, istilah Darul Islam lebih populer dengan singkatan DI saja. Pada mulanya, pemerintah RI di Yogyakarta tidak segan-segan memberi bantuan semampunya kepada DI, karena dianggap melanjutkan perjuangan Proklamasi 17 Agustus 1945. Namun, pada Akhirnya pemerintah mengambil tindakan tegas ketika pasukan DI mulai melakukan aksi peracunan, penjebakan, dan perampasan. ${ }^{10}$

S.M. Kartosuwirjo beranggapan bahwa seluruh wilayah Jawa Barat merupakan wilayah de facto NII. Mulamula basisnya di Cisayong
Tasikmalaya, kemudian pindah ke Gunung Cupu Ciamis, dengan alasan posisinya yang lebih strategis. Pada tanggal 17 Februari 1948 berlangsung pertempuran hebat antara pasukan TII dengan Belanda di Gunung Cupu. Momen tersebut diabadikan menjadi Hari Angkatan Perang DI/TII. ${ }^{11}$ Beberapa pasukan yang bergabung dengan TII, antara lain Laskar Bambu Runcing dan Pasukan Siluman yang merupakan bagian dari laskar Pangeran Papak. Pada tanggal 7 Agustus 1949 S.M. Kartosuwirjo mem-proklamasikan Negara Islam Indonesia (NII) atau Negara Darul Islam (DI).

Sejak Konferensi di Cipeundeuy Majalengka, para pemimpin Islam sudah melakukan penentangan terhadap ide S.M. Kartosuwirjo. Bagi mereka, ide pendirian Negara Islam tidak lain bertujuan melenyapkan Republik Indonesia. Akibatnya, beberapa pasuan kembali ke daerah asal melanjutkan perjuangan melawan Belanda. Klaim teritorial S.M. Kartosuwirjo menimbulkan bentrokan hebat dengan pasukan yang kembali. Ia menuduh pasukan lain yang masuk telah melanggar kedaulatannya. Mau tidak mau mereka harus mengakui kedaulatan NII. Bila tidak, mereka harus bersedia dilucuti bahkan diperangi. Konflik sesama pejuang Republik semakin mengeras.

Akibat Agresi Militer Belanda kedua Ibukota Republik Indonesia, Yogyakarta, jatuh. Divisi Siliwangi dan Laskar Darussalam melakukan Long March kembali ke Jawa Barat. S.M. Kartosuwirjo menuduh kedua pasukan tersebut sebagai tentara liar dan pelarian pengikut PKI Madiun. Mereka menghadapi situasi sulit. Selain harus

${ }^{10} \mathrm{Ibid}, \mathrm{hlm} .176$

${ }^{11}$ Ibid, hlm. 118 
berperang dengan Belanda, mereka berhadapan pula dengan gerombolan DI/TII. Terjadilah pertempuran segitiga antara TNI, DI/TII, dan pasukan Belanda. Konflik bersenjata tidak dapat dielakkan lagi. Clash pertama yang melibatkan Divisi Siliwangi dengan DI/TII terjadi pada tanggal 25 Januari 1949 di Antralina, Malangbong Garut.

Pihak Cipari harus berhadapan dengan dua musuh sekaligus. Di siang hari mereka harus menghadapi operasi pasukan Belanda, dan di malam hari menahan serangan pasukan DI. K.H. Yusuf Tauziri terus memompakan semangat perjuangan pada laskar dan penduduk. Kiai Yusuf ngaharamkeun mundur sanajan salambar buuk 'mengharamkan mundur meskipun selembar rambut'. Dalam rangka melindungi diri dari tangkapan musuh, penduduk Cipari membuat lubang-lubang perlindungan. Pernah suatu ketika datang patroli Belanda secara tidak terduga dan berhasil menemukan lubang perlindungan. Beberapa ulama ditangkap dan sebelas pucuk senjata serta sembilan mesin ketik turut disita. Mereka dibawa ke markas pasukan Belanda. Di tempat tersebut, mereka ditanya dari mana senjata diperoleh dan akan dipergunakan untuk keperluan apa. Dijawab oleh salah satu dari ulama Cipari bahwa senjata tersebut dipakai untuk menahan gempuran DI yang menyerang kampung. Belanda tidak mengetahui bahwa senjata tersebut digunakan menyerang patrolinya. Namun, setelah dilihat senjata-senjata tersebut terlihat tidak ada tanda-tanda bekas dipakai. Akhirnya, Belanda melepaskan para kiai, karena tidak memiliki cukup bukti. ${ }^{12}$

\section{Perbedaan Pandangan Yusuf Tauziri - Kartosuwirjo}

Jawaban terhadap tumbuhnya konflik antara Darussalam dengan DI/TII dapat dilacak dari perbedaan perjuangan antara K.H. Yusuf Tauziri dengan S.M. Kartosuwirjo. Perbedaan tersebut, di antaranya berkenaan dengan "kerja sama" dengan penjajah, konsepsi Negara Islam, dan sikap politik terhadap hasil perjanjian Renville.

Sebagaimana dijelaskan pada subbab sebelumnya bahwa S.M. Kartosuwirjo mengambil tindakan keras dalam hubungannya dengan penjajah. Sementara, K.H. Yusuf Tauziri tahu benar bagaimana memanfaatkan keahlian lawan untuk pada akhirnya menghancurkan lawan. Kooperasi dan non-kooperasi menjadi taktik yang sering dipakai secara bergantian.

K.H. Yusuf Tauziri pernah mengusulkan kepada penguasa Militer di Garut yakni Kolonel De Jong agar pemuda Darussalam mendapat pelatihan kemiliteran. Tujuannya ialah agar dapat membantu Belanda memerangi DI/TII. Belanda dapat memahaminya dan permintaan tersebut dikabulkan. Maka latihan kemiliteran pun berlangsung hingga tahun 1949. Sebenarnya, para pemuda yang dianggap tidak memiliki keterampilan militer tersebut adalah anggota laskar Darussalam dan anggota TNI. Dengan demikian, pengetahuan dan pengalaman yang mereka peroleh semakin bertambah.

12 Transkrip wawancara Wahyudi dengan H. Marko di Cipari, 2 April 2005. 
Dengan "kedekatan" tersebut anggota TNI yang kembali dari Long March saat melintasi daerah-daerah yang berada di bawah pengaruh Darussalam tidak mendapat gangguan yang cukup berarti.

Bagi DI/TII, apa yang dilakukan pihak Darussalam merupakan tindakan menabuh genderang perang. Hal tersebut, tidak dapat dimaafkan. Maka setiap kali DI/TII menyerang Darussalam, mereka selalu berteriak "yeuh mentega ti Wihelmina 'nih (rasakan) mentega dari Wihelmina!" sambil melontarkan bom. Sindiran dan hinaan yang bernada kebencian sering dialamatkan DI/TII kepada pihak Darussalam.

Banyak orang bumiputra yang dijadikan alat oleh Kartosuwirjo untuk tujuan politisnya sehingga terjadi bentrokan senjata antara pengikut Islam di pihak pemerintah RI menghadapi pengikut Islam di pihak Kartosuwirjo. Akibat pemberontakan itu, selain banyak menelan korban manusia dan materi, juga merusak mentalitas manusianya. ${ }^{13}$

Persoalan kedua menyangkut pemahaman tentang konsepsi Negara Islam. S.M. Kartosuwirjo memiliki konsepsi yang tegas tentang Negara Islam. Ia merujuk pada permulaan abad pertama Hijriyah ketika Rasulullah saw. membentuk Masyarakat Islam. Baginya, Islam adalah agama dan negara (al-addien wa al-daulah). Gagasan Negara Islam, dalam pandangan Kartosuwirjo, bukanlah suatu ilusi, melainkan kenyataan

\footnotetext{
${ }^{13}$ Kunto Sofianto, Garoet Kota Intan: Sejarah Lokal Kota Garut Sejak Zaman Kolonial Belanda Hingga Masa Kemerdekaan (Jatinangor: Alqaprint), 2001, hlm. 131
}

sejarah yang pernah diterapkan di masa lalu. Oleh karena itu, dalam pemahaman Kartosuwirjo, sebagaimana "Negara Madinah" yang dibangun Nabi Muhammad saw., Negara Islam merupakan empirical political theory (teori politik empirik) dan normative political theory (teori politik normatif) sekaligus. Negara merupakan sarana untuk mewujudkan praktik syariat Islam. Selain Negara Islam, yang maujud hanyalah Negara Thogut yang tidak berdasar atas Syariat Islam.

Berbeda dengan Kartosuwirjo yang strukturalis, agaknya bagi K.H. Yusuf Tauziri, yang terpenting adalah bagaimana mengislamkan masyarakatnya, bukan mengislamkan negaranya (maksudnya: mendirikan Negara Islam). K.H. Yusuf sering berkata di depan pasukannya,

“...lamun imah ruksak di salah sahiji bagian imah saperti panto, ulah diruksak sakabeh imah, tapi panto weh nu kudu dibenerkeun ... jeung ulah sakali-kali nyieun imah di jero imah".

Artinya:

“... kalau rumah rusak di antara salah satu tubuh rumah seperti pintu, jangan dirusak semuanya (rumah) tetapi pintu saja diperbaiki... dan jangan pernah membuat rumah di dalam rumah". ${ }^{14}$

Secara intens K.H. Yusuf Tauziri mempelajari Undang-Undang Dasar DI. Ia berpendapat bahwa DI tidak memperjuangkan ajaran Islam yang sebenarnya. Hal tersebut ia diskusikan

April 2009

${ }^{14}$ Wawancara H. Salaf Soleh, Cipari, 29 
pula dengan Haji Ahmad Sanusi dan beberapa kiai serta ulama lainnya. Simpulannya, perjuangan DI tidak sepatutnya didukung oleh umat Islam. Tentu saja, dengan perbedaan ideologis tersebut, K.H. Yusuf Tauzirie tidak dapat menerima tuntutan dan ajakan S.M. Kartosuwirjo untuk ikut bergabung memproklamasikan Negara Islam Indonesia. Bahkan, pada saat Jepang menyerah dalam Perang Dunia ke-2, pada tanggal 15 Agustus Kartosuwirjo memintanya untuk memproklamasikan NII (Negara Islam Indonesia). Akan tetapi permintaan tersebut ditolaknya. ${ }^{15}$

Sebenarnya K.H. Yusuf Tauzirie tidak setuju dengan hasil persetujuan Renville yang secara de facto makin mempersempit wilayah RI. Namun, K.H. Yusuf Tauziri menyikapinya dengan kebesaran jiwa dan loyalitas yang tinggi terhadap pemimpin bangsa. Oleh karena itu, K.H. Yusuf Tauzirie membagi laskar Darussalam menjadi dua pasukan. Sebagian ikut hijrah (termasuk anaknya, Saep Darmawan) dan bergabung dengan Batalyon Husinsyah. Di Yogyakarta, laskar Darussalam bergabung dengan Batalyon XI Mayor Umar Wirahadikusumah. Sebagian lagi, tetap berada di "kantung-kantung perlawanan". Dipimpin K.H. Yusuf Tauzirie, laskar Darussalam, Hizbullah dan Sabilillah melakukan perlawanan terhadap Belanda. Basis perlawanannya di Gunung Cupu Ciamis.

Kartosuwirjo dengan tegas menolak hasil Perjanjian Renville. Pasukannya yang berkekuatan 4.000 orang yang berasal dari Hizbullah dan

15 C. van Dick, Darul Islam sebuah Pemberontakan (Jakarta: Grafiti Pers), 1995, hlm. 5
Sabilillah tetap melakukan perjuangan di Jawa Barat. Agaknya Kartosuwirjo mencari momentum yang tepat untuk mendirikan Negara Islam Indosesia (NII). Momen tersebut adalah ketika tentara Divisi Siliwangi hijrah ke Jawa Tengah dan berdirinya Negara Pasundan di Jawa Barat.

Ketika terbit Maklumat-maklumat Komandan Tertinggi Angkatan Perang Negara Islam Indonesia (APNII) No.4 dan 5, konflik semakin meruncing. Maklumat tersebut mewajibkan peleburan semua tentara ke dalam Tentara Islam Indonesia (TII) dan melarang semua partai dan organisasi. Sudah pasti hal tersebut menimbulkan gesekan yang keras di antara kekuatan laskar dan partai Islam.

K.H. Yusuf Tauzirie tidak berkenan dengan cara-cara DI/TII menagih pajak (infaq) dengan cara paksa. Hal itu dipandang semakin menambah beban penderitaan rakyat. Tujuan baik apabila dijalankan dengan cara yang tidak benar tetap saja menjadi salah. S.M. Kartosuwirjo menyebut ulama-ulama yang menentangnya sebagai "ulama bughot" (ulama pembangkang). ${ }^{16}$

\section{Konflik Laskar Darussalam-TNI dengan DI/TII}

Sejak Agresi Militer Belanda II, S.M. Kartosuwirjo mengklaim daerah Jawa Barat sebagai wilayah de facto NII. Maka, bentrokan fisik terjadi ketika Divisi Siliwangi dan badanbadan perjuangan kembali ke Jawa Barat. Sudah jelas, bagi Kartosuwirjo, kedatangan pasukan-pasukan tersebut sebagai pelanggaran terhadap kewibawaan Negara Islam Indonesia. Selama

${ }^{16}$ Wawancara H. Syarif Hidayat, Cipari, 30 April 2009. 
hampir enam bulan lamanya di tahun 1949, permusuhan antara TNI (termasuk laskar Darussalam) dengan DI/TII semakin menguat.

Di Garut, pasukan DI terpusat di beberapa daerah pedalaman, seperti sekitar Gunung Guntur, Leles, Balubur Limbangan, Cibatu, Malangbong, dan sekitar Gunung Cikuray. Para gerilyawan DI menyebut daerah ini daerah suffah, yaitu daerah suci yang telah dibersihkan dari musuh. Sejumlah lokasi tersebut menjadi pangkalan untuk menyerang Garut.

Kontak senjata antara DI/TII dengan pasukan Mayor Rivai terjadi pada tanggal 25 Januari 1949 di Antralina Malangbong Garut, yang juga disebut sebagai peristiwa Antralina. Dua hari setelahnya (27 Januari 1949), S.M. Kartosuwirjo menyampaikan ultimatum agar pihak Pesantren Darussalam secepatnya mengambil sikap, apakah berada di pihak DI atau RI. Sepucuk surat dilayangkan Kartosuwirjo melalui utusannya, antara lain Jaja, Sanusi Parta, Toha Arsyad dari Ciawi. Utusan DI diajak berunding oleh K.H. Yusuf di rumah Hj. Muti'ah. K.H. Yusuf mengatakan bahwa tiaptiap sesuatu ada waktunya. Apa yang diperjuangkan Kartosuwirjo belum sampai pada waktu yang tepat. Selain itu, Kartosuwijo melalui suratnya meminta agar pasukan pengikut K.H. Yusuf diserahkan ke Negara Islam. Akan tetapi, permintaan itu ditolaknya. ${ }^{17}$

Sementara itu, masyarakat sudah membaca gelagat yang membahayakan tersebut. Penduduk desa sekitar seperti biasa mengungsi ke masjid dan

17 Transkrip wawancara Wahyudi dengan Haji Marko di Cipari 2 April 2005. madrasah Cipari setelah Dzuhur. Mereka membawa perlengkapan seadanya dan memasak makanan di halaman masjid. Mereka bermalam di tempat itu, dan pulang ke desa masing-masing pada keesokan harinya.

Pada tanggal 30 Januari 1949, Tentara Siliwangi yang dipimpin Mayor Rivai tiba di Pesantren Cipari. Dari kejadian itu, bagi S.M. Kartosuwirjo, menjadi jelaslah posisi Darussalam berada. Ia begitu geram dengan mantan koleganya itu. Segera setelah tentara Siliwangi meninggalkan Pesantren Darussalam, Pasukan DI/TII menyerang Kampung Cipari. Tujuan dari penyerangan itu adalah menangkap K.H. Yusuf Tauziri. Rumah-rumah penduduk digeledah. Sekitar 30 orang anggota laskar Darussalam ditangkap. Mereka harus menyatakan kesetiaannya pada DI. Bila tidak, mereka akan dibunuh.

Beberapa kali penyerangan terjadi sepanjang tahun 1949-1958. Satu sumber menyebut terjadi 50 kali (ada juga yang menyebut 52 kali) serangan Resimen Kalipaksi dan Sapujagat DI/TII menyerang Cipari. Namun yang terbesar adalah serangan tanggal 17 April 1952 dan 5 Agustus 1952. Hiroko Horikoshi melukiskan Peristiwa 17 April 1952 sebagai berikut,

"the battle lasted until three o'clockin the morning, shortly before the subuh (dawn) prayers. During the night the three thousand TII soldiers made three advances".

Artinya:

"tembak menembak itu berlangsung sampai pukul tiga 
pagi, dan berhenti sebelum sholat Subuh tiba, sekitar 3.000 anggota TII melakukan tiga kali serangan".

Pasukan DI/TII menyerbu Cipari dari arah selatan. Hal ini di luar kelaziman, karena biasanya gerombolan DI/TII menyerang dari gununggunung sebelah utara dan hari sudah beranjak malam. Mereka mengepung Cipari sekitar Isya atau pukul setengah tujuh malam. Sebagian penduduk di sekitar kawasan Cipari mengungsi ke Gedung Madrasah dan Masjid Cipari. K.H. Yusuf Tauzirie dan pasukannya bertahan dengan tujuh senapan tua, pistol dan granat tangan.

Di Cipari, orang yang mula-mula melihat kedatangan gerombolan DI/TII adalah seorang kiai, sepupu K.H. Yusuf Tauziri dari pihak ibu. Rumahnya berada di tepi jalan ke arah desa. Seperti kebiasaan yang sudah-sudah, ia dan keluarganya mengungsi ke Cipari di malam hari. Ia menceritakan pengala-mannya kepada Tempo sebagai berikut:

"Pada hari itu saya menghadiri rapat di Cimahi, dan baru sore hari berganti pakaian ketika istri saya membisikkan, ada patroli di luar rumah. Segera saja saya menyadari bahwa itu bukan patroli biasa, dari pos polisi kecamatan, melainkan sepasukan DI/Tll yang sedang bergerak ke arah desa. Saya tarik badan istri saya, dan kami bersembunyi di balik tirai sambil mengintip. Tidak biasanya TII datang ke desa sesore itu, dan dari arah selatan pula. Biasanya mereka muncul dari gunung-gunung sebelah utara. Hari itu saya terlambat pergi ke Madrasah, tapi hal itu pulalah yang menyelamatkan jiwa kami."

Berita kedatangan DI ke Cipari, diketahui juga oleh $\mathrm{Hj}$. E. Kuraesin, adik kandung Yusuf Tauzirie. Berikut penuturannya kepada Tempo:

"Kami mendengar berita Pasukan DI/TIII sudah mendekat Cipari menjelang Isya, sekitar pukul setengah tujuh malam. Sejak Maghrib, sebagian besar penduduk mengungsi ke Cipari masuk ke gedung madrasah. Tapi karena rumah kami berdekatan dengan madrasah, kami masih berada di rumah. Kakak perempuan saya yang selalu kebingungan, jika ada hal-hal yang tak lazim, mulai berteriakteriak,"DI sudah datang!" melompat ke sana kemari. Mulamula saya tak percaya, karena masih terlalu sore. Tapi ketika saya melihat rumah di seberang rumah kami mulai dimakan api, kemudian mendengar bunyi kentongan dipukul, keraguan saya lenyap. Ibu saya yang berusia delapan puluh tahun, meloncat lewat jendela bersama dua cucunya. Melalui pekarangan rumah mereka berlari ke madrasah. Saya membantu kakak saya yang ketakutan, dan kami selamat juga sampai di madrasah".

${ }^{18}$ Sebuah menara dalam kepungan d.i., dalam http://majalah.tempointeraktif.com 
Gerombolan DI/TII masuk melalui pertigaan jalan raya menuju Cibatu, lalu bergerak ke jalan perkampungan Desa Cimaragas dan mengarah ke Kampung Cipari. Gerombolan yang berjumlah sekitar 3.000 orang sepanjang perjalanan melakukan teror. Mereka membakar rumah-rumah penduduk yang dilaluinya. Tidak ada perlawanan dari penduduk. Setelah mencapai Cipari sekitar pukul tujuh malam, berlangsung kontak senjata antara DI/TII dengan laskar Darussalam yang dibantu penduduk setempat hingga pukul tiga dini hari. K.H. Yusuf Tauziri dan laskarnya bertempur dengan tujuh pucuk senapan, pistol buatan Kanada, lima karaben Jepang di antaranya peninggalan Pasukan Siliwangi dan dua senapan dorlok buatan dalam negeri, serta granat tangan. Pasukan DI/TII menyerbu rumah-rumah, dan mulai menyerang Masjid Cipari.

K.H. Yusuf Tauziri memimpin perlawanan masyarakat Cipari. Dari menara masjid, ia melepaskan granat ke arah pasukan TII yang mengepung masjid. Dalam kobaran api yang menghanguskan rumah-rumah, bayangan tubuhnya terlihat dari kejauhan seperti wayang kulit yang bergerak-gerak di layar. Lebih lanjut H. E. Kuraesin menuturkan,

"Waktu itu abang saya, Kiai Yusuf, sudah berada di puncak masjid. Adanya menara ini rupanya memang sudah takdir Tuhan. Karena, saya ingat benar, ketika abang saya mendirikan komplek masjid-madrasah itu kurang lebih dua puluh tahun sebelumnya, dalam rencana yang dibuat tidak ada gambar menara itu. Tapi karena satu dan lain hal abang saya berkeras menambahkannya, diletakkan di antara masjid dan madrasah. Berkat Allah jugalah, karena ternyata ribuan orang telah diselamatkan dari maut dalam peristiwa itu."

Kaca jendela madrasah tempat pengungsi bertahan hancur. Sebagian pengungsi yang bertahan di dalam terluka terkena serpihan kaca. Lamanya aksi tembak-menembak berlangsung mengakibatkan dua senapan pihak Cipari mengalami kerusakan akibat terlalu panas. Sisanya yang lima pucuk masih dapat digunakan. Namun, satu senapan lagi tidak dapat digunakan. Demikian pula, persediaan peluru makin menipis.

Oyoh, salah seorang pengawal K.H. Yusuf Tauzirie, tidak dapat lagi menembakkan senjatanya. Namun, kesetiaannya yang tinggi terhadap pemimpinnya membuat ia mengambil keputusan nekad. Dengan gagah berani, diambilnya granat tangan dan keluar madrasah, lalu mendekati batas kepungan TII. Granat tangan yang berada dalam genggamannya, ia lontarkan ke arah pasukan TII. Ia segera berbalik arah menuju madrasah. Baru saja berlari, peluru TII bersarang di tubuhnya, dan ia tewas seketika.

Persediaan peluru kian menipis, akan tetapi untunglah jumlah granat yang dimiliki cukup banyak. Untuk menghemat peluru, maka K.H. Yusuf Tauzirie memerintahkan pasukannya agar hanya menembak musuh yang bergerak maju ke masjid saja. Strategi tersebut ternyata cukup efektif dalam menghemat amunisi. 
Pasukan TII terus mendesak maju. Mereka berusaha mendobrak tembok bagian barat masjid. Tembok itu tidak berjendela. Pasukan TII berusaha meledakkan tembok dengan granat. Namun usaha tersebut tidak membuahkan hasil, karena temboknya cukup tebal sekitar $40 \mathrm{~cm}$. Hanya sebuah lubang kecil saja yang menganga sebesar lubang untuk masuk senapan TII. Dalam serangan tersebut, korban tewas di pihak Darussalam sebanyak empat anggota pasukan pengawal dan tujuh penduduk. Sementara itu, 13 orang menjadi korban dari pihak DI/TII.

Menjelang subuh, Pasukan D1/TII mundur ke arah pegunungan sebelah utara Kampung Cipari. Dapat dikatakan bahwa tujuan penyerangan tersebut tidak sesuai dengan harapan. Hanya sekadar menciptakan ketakutan dan trauma di tengah-tengah masyarakat. Orang-orang Cipari yang sebelumnya mengungsi kembali ke rumah masing-masing. Pagi hari mereka melihat puing-puing rumah yang habis terbakar. Beberapa saat kemudian datanglah rombongan Palang Merah Indonesia dari Garut membawa makanan dan pakaian. Pada sore hari itu juga Gubernur Jawa Barat Sanusi Hardjadinata tiba dari Bandung bersama Kepala Staf Angkatan Perang Jenderal Simatupang dari Jakarta. Mereka menyampaikan duka cita mendalam atas korban yang tewas sekaligus menunjukkan kekagumannya atas keberanian laskar dan penduduk Cipari. Dalam rombongan itu, ikut pula seorang dokter Jerman untuk merawat yang luka-luka. ${ }^{19}$

${ }^{19}$ Sebuah menara dalam kepungan d.i., dalam http://majalah.tempointeraktif.com
Pada hari-hari berikutnya, kehidupan berjalan normal kembali. Di balong (kolam ikan) dan sawah ditemukan sepuluh mayat pasukan DI/TII. Sejak itu, tidak ada seorang pun yang mau memakan ikan dari balong tersebut. Demikian pula, dalam waktu yang cukup lama penduduk enggan untuk bersawah kembali. Mereka masih merasakan trauma akibat serangan itu.

Bertahun-tahun lamanya penduduk masih mengingat dengan jelas kejadian yang luar biasa tersebut, dan selalu menghubungkannya dengan K.H. Yusuf Tauziri. Misalnya, dari atas menara ia mampu melemparkan granat berpuluh-puluh meter jauhnya. Ia tidak tertembak padahal berdiri di menara yang dapat dengan mudah ditembak. Bahkan ada cerita, letusan pistolnya laksana suara brend. $^{20}$ Penduduk percaya, kiai itu telah mencapai tingkat tertinggi dalam tasawuf, yaitu ma'rifat. Ia dianggap memiliki kekuatan gaib.

Pada tanggal 5 Agustus 1952, pasukanDI/TII menggempur kembali Kampung Cipari. Tokoh-tokoh Cipari yang turut terlibat dalam peristiwa tersebut, antara lain Yusuf Tauzirie, K.H. Abdul Kudus, K.H. Abbas, Ahmad Marko, Bahtiar, Solihin, Saep Darmawan, dan Asikin. Koran Pikiran Rakyat menuliskan laporannya tentang peristiwa tersebut,

"Djumlah orang-orang yang menjadi korban serangan atas Kampung Tjipari Sukawening Kecamatan Wanaradja Garut tanggal 5 Agustus itu adalah 24 orang meninggal, 23 orang mendapat luka, jumlah rumah yang terbakar di Tjipari ada 58 buah.

20 Transkrip wawancara Wahyudi dengan Muhammad Sadjili dan Salaf Soleh di Cipari tanggal 30 Maret 2005. 
Pengumuman itu membenarkan beritaberita bahwa gerombolan itu memusatkan serangannya kepada pesantren, rumah dan masjid K.H. Yusuf Tauzirie. Tapi kyai itu sekarang masih selamat. Selanjutnya diterangkan bahwa gerombolan sekarang itu telah terpukul mundur ke daerah Tjisitu, Sadahurip dan Tjinta. Mengenai djumlah korban yang mening-gal tersebut di atas dapat terbagi kedalam 15 korban mayat gerombolan dan 9 mayat penduduk Tjipari."

Sekitar 1.500 pasukan DI/TII dengan persenjataan lengkap menyerang dari tiga posisi, yaitu sebelah utara daerah pesawahan, sebelah timur Kampung Situ Saeur, dan sebelah jalan perkampungan Desa Cimaragas yang memiliki akses langsung menuju Cipari. Gerombolan DI/TII membawa senjata, antara lain brend, standgun, dan mortir. Laskar Darussalam dan masyarakat Cipari sudah membangun benteng pertahanan guna mengantisipasi serangan DI/TII. Kali ini tujuan serangan adalah membumihanguskan Pesantren Cipari.

Agaknya pihak pesantren sudah bersiap-siap menyambut serangan. Berbeda dengan kejadian sebelumnya, kali ini pihak Cipari menyiapkan strategi peperangan yang ofensif. Sebelum mencapai Kampung Cipari, pasukan Darussalam sudah menghadang pasukan DI/TII di luar kampung. Namun, hadangan tersebut dapat dilumpuhkan pasukan Dl/Tll. Mereka langsung bergerak masuk dan membakar Kampung Cipari. Pasukan Darussalam makin terdesak, dan berlindung di Masjid Cipari.

Meski pasukan DI/TII berhasil mengepung Masjid Cipari, namun mereka tidak berhasil masuk. K.H. Yusuf Tauzirie memberi komando perlawanan dari menara masjid. Ia menyandang standgun dan granat, dan menembaki pasukan DI/TII yang mencoba memasuki masjid. Menara masjid yang memiliki tinggi dua puluh meter dan bergaris tengah satu meter sangat strategis. Dari menara tersebut, K.H. Yusuf Tauziri dapat memantau gerakan pasukan DI/TII. Pasukan DI/TII berusaha menghancurkan menara tersebut, tetapi mengalami kegagalan. Pasukan DI/TII akhirnya ditarik mundur. Sama halnya dengan peristiwa sebelumnya, kali ini misi serangan DI/TII juga kandas. Sekitar 24 orang tewas, 23 orang luka-luka. Selain itu, 58 rumah habis terbakar. Gerombolan DI/TII gagal menghancurkan Cipari, desa Islam orthodoks yang pada mulanya menyokong dan kemudian menentang dengan gigih kekuatankekuatan Kartosuwirjo. $^{21}$

\section{Akhir Konflik}

Sebagaimana disebutkan sebelumnya, kemarahan S.M. Kartosuwirjo terhadap K.H. Yusuf Tauziri sungguh tak tertanggungkan. Beberapa kali penyerangan dilakukan, baik yang bersifat sporadis maupun besarbesaran. Akhirnya, serangan DI/TII terhadap Darussalam terus berkurang. Hal tersebut disebabkan gerak ofensif TNI yang menumpas pasukan DI/TII semakin meningkat. Selain itu, kekuatan laskar Darussalam makin bertambah dengan dukungan batalyon

21 Karl D. Jackson, Kewibawaaan Tradisional, Islam, dan Pemberontakan: Kasus Darul Islam Jawa Barat (Jakarta: Pustaka Utama Grafiti), 1990, hlm. 133 
setempat dan Perwira Staf Militer (PSM).

Pasukan Darussalam membantu TNI menumpas DI/TII di daerah Wanaraja pada tahun 1954. Kemudian, turut serta melumpuhkan kekuatan DI/TII di Kampung Cinta Sukawening. Peranan pasukan Darussalam dalam operasi militer TNI amat penting, karena mereka tahu secara persis wilayah-wilayah yang akan dibersihkan dari unsur DI/TII.

Strategi peperangan Divisi Siliwangi untuk menghancurkan kekuatan DI/TII menciptakan taktik "isolasi total", yang kemudian populer dengan sebutan "pagar betis". Wilayah Jawa Barat dibagi menjadi 3 Daerah Operasi (DO), yaitu tipe A, B, dan C. Daerah Operasi (DO) A adalah daerah yang sudah normal, terbebas dari pengaruh DI/TII. DO-B adalah wilayah yang sudah mampu dikontrol TNI, meski gangguan DI/TII masih terjadi. DO-C adalah daerah yang masih dikuasai DI/TII. Melalui operasi "pagar betis" DO-C semakin berkurang, dan menjadi DO-B, untuk kemudian DO-A. Dalam taktik "Pagar Betis" partisipasi rakyat sangatlah penting. Divisi Siliwangi tidak dapat bekerja sendiri, melainkan dengan partisipasi aktif rakyat Jawa Barat.

Operasi "Pagar Betis" sedikit demi sedikit terus mengurangi kekuatan DI/TII sepanjang 1958 hingga tahun 1960-an. Daerah-daerah yang menjadi kantong DI satu demi satu berhasil direbut. Akhirnya, gerakan DI/TII berhasil dipatahkan dengan tertangkapnya S.M. Kartosuwirjo pada tanggal 4 Juni 1962 pukul 11.35 di daerah Gunung Geber Priangan Tengah. Kompi "C" Batalion 328/
Kujang II berperan penting dalam aksi penang-kapan itu.

Pesantren Darussalam Cipari berhasil melalui salah satu pergolakan sosial yang paling keras dalam sejarah nasional. Kegiatan pesantren berlangsung dengan lancar. Agaknya ujian sejarah tidak pernah padam. Gerakan komunis menyebar dan menciptakan rasa permusuhan di kalangan elit dan masyarakat. K.H. Yusuf Tauziri bersama rakyat berjuang melawan paham komunis yang sudah berkembang di masyarakat. Ia turut mempersiapkan organisasi PII (Pelajar Islam Indonesia) untuk menghadapi situasi sulit. Pasukan Darussalam berjuang bersama TNI menumpas PKI mulai dari wilayah Garut, Tasikmalaya, Bandung, Sumedang, Ciamis hingga ke Yogyakarta.

Pada bulan Agustus 1952, K.H. Yusuf Tauzirie kembali ke Wanaraja, dan membangun kembali rumah dan madrasah yang dibumihanguskan oleh pasukan Pangeran Papak. Sementara itu, aktivitas Pesantren Darussalam dibimbing oleh kakaknya, yaitu K.H. Abdul Kudus. Tahun 1966, kepemimpinan pesantren dilanjutkan oleh Kiai Mansur dan sepupunya. K.H. Yusuf Tauziri aktif di Divisi III Siliwangi bagian perawatan rohani.

\section{PENUTUP}

Riwayat Pesantren Darussalam Cipari adalah sejarah pergulatan panjang pesantren dalam dinamika perjalanan bangsa. Pesantren sebagai subkultur kebudayaan telah mereposisikan dirinya sedemikian rupa dengan perkembangan zaman. Dalam konteks ini, pesantren bukan hanya dibentuk, 
tetapi memberi warna bagi pencarian identitas kebangsaan.

Pesantren Cipari menjadi wadah persemaian para nasionalis sejati. Ketika proklamasi dikumandangkan, pihak pesantren segera berdiri di belakang tokoh-tokoh republik menyatakan kesetiaannya. Demikian pula, ketika Belanda yang berkehendak untuk kembali menjajah, K.H. Yusuf Tauziri masuk dalam barisan terdepan menyelamatkan Republik yang masih amat muda ketika itu.

Loyalitas K.H. Yusuf Tauziri dan Pesantren Cipari terhadap pemimpin bangsa diuji kembali oleh hasil Perjanjian Renville yang merugikan RI. Betapapun ia kecewa dengan perundingan itu, namun ia berbesar hati untuk menerimanya. Sebagian dari para pengikutnya diikutsertakan dalam politik "hijrah", termasuk putranya sendiri. Hal itu pulalah yang meretakkan hubungannya dengan S.M. Kartosuwirjo. Ia dipaksa untuk memilih apakah berdiri di pihak DI/TII atau RI. Ia memilih opsi yang kedua, dan berjuang bersama TNI dan rakyat menumpas gerakan TII.

Pemikiran tokoh Pesantren Cipari yang terepresentasikan dalam diri K.H. Yusuf Tauziri tentang kebangsaan amatlah jelas. Ia tidak berterima dengan negara Islam, karena yang terpenting mengislamkan masyarakat, dan bukan mengislamkan negaranya. Islam dan kebangsaan tidak perlu diper-tentangkan, bahkan dapat dipertemukan.

Salah satu warisan terpenting dari kehidupan K.H. Yusuf Tauziri adalah sikap kemandiriannya. Ia teguh mempertahankan prinsip yang akan dipertahankannya walaupun orang mengajak berselisih. Konfliknya dengan S.M. Kartosuwirjo menjadi gambaran yang jelas mengenai keteguhannya dalam memegang prinsip.

Para ulama Pesantren Cipari memegang peranan penting dalam upaya mempertahankan integrasi bangsa. Para pewaris ajaran rasul tersebut menyerukan persatuan membela kemerdekaan RI yang diproklamasikan SoekarnoHatta. Kesetiaan terhadap Repulik ditunjukkan ketika Kiai Yusuf lebih memilih berjuang mempertahankan kemerdekaan daripada bergabung dengan DI/TII pimpinan S.M. Kartosuwirjo. Hal tersebut tentu berpengaruh terhadap para pengikutnya yang setia untuk loyal terhadap Negara Kesatuan Republik Indonesia.

\section{DAFTAR PUSTAKA}

1. Buku dan Artikel

Awwas, Irfan S. 2008.

Jejak Jihad S.M. Kartosuwijo; Mengungkap Fakta yang Didustakan. Yogyakarta: Uswah.

Dhofier, Zamakhsari. 1985.

Tradisi Pesantren: Studi tentang Pandangan Hidup Kiai. Jakarta: LP3ES.

Horikoshi, Hiroko. 1982.

Kiai dan Perubahan Sosial. Terjemahan Umar Basalim. Jakarta: P3M.

Jackson, Karl D. 1990.

Kewibawaaan Tradisional, Islam, dan Pemberontakan: Kasus Darul Islam Jawa Barat. Jakarta: Pustaka Utama Grafiti.

Pui Huen, P. Lim et al. (ed.). 2000. 
Sejarah Lisan di Asia Tenggara:

Teori dan Metode (Jakarta: LP3ES).

Rahardjo, M. Dawam. 1993. Intelektual Inteligensia dan Perilaku Politik Bangsa, Risalah Cendekiawan Muslim. Bandung: Mizan.

Rismawa, Asep Tedi. 2008.

"Perlawanan Laskar Darusslam terhadap Gerakan DI/TII di Wanaraja Garut 1948-1952." Skripsi. Jurusan Sejarah dan Peradaban Islam, UIN SGD Bandung.

Sofianto, Kunto. 2001.

Garoet Kota Intan: Sejarah Lokal Kota Garut sejak Zaman Kolonial Belanda Hingga Masa Kemerdekaan. Jatinangor: Alqaprint.

Transkrip wawancara Wahyudi dengan Muhammad Sadjili dan Salaf Soleh di Cipari tanggal 30 Maret 2005.

Transkrip wawancara Wahyudi dengan Haji Marko di Cipari 2 April 2005.

van Dick, C. 1995.

Darul Islam sebuah Pemberontakan. Jakarta: Grafiti Pers.

Ziemek, Manfred. 1986.

Pesantren dalam Perubahan Sosial. Terjemahan Butche B. Soendjojo. Cet ke-1 . Jakarta: P3M.

\section{Internet}

"Dampak Perubahan Orientasi Pondok Pesantren Terhadap Masyarakat", http: www.pondok-pesantren.net, 24 September 2008.

Sebuah Menara dalam Kepungan d.i., http:/majalah.tempointeraktif.co m, diakses 15 Juli 2009.

"Tantangan Pesantren di Era Multikulturalisme", http:// K.H. amamizadamultiply.com/journ al/item/7, diakses 15 Agustus 2009.

\section{Wawancara}

Fuadz, Nasrul (31 tahun).

Guru Madrasah.

Wawancara, Cipari, 30 April 2009.

Hidayat, Syarif (75tahun)

Sekretaris Yayasan (Sesepuh).

Wawancara, Cipari, 30 April 2009.

Sholeh, Salaf (72 tahun).

Anggota Yayasan-Pembina

Asrama.

Wawancara, Cipari, 30 April 2009. 